Published in final edited form as:

Lancet. 2003 August 30; 362(9385): 678. doi:10.1016/S0140-6736(03)14243-2.

\title{
Health and development
}

\author{
Jennifer Prah Ruger \\ Department of Medicine, Division of General Medical Sciences, Washington University School of \\ Medicine, St Louis, MO 63110, USA (jruger@im.wustl.edu)
}

In one of her last public speeches as Director-General of the WHO on May 19, 2003, Gro Harlem Brundtland reiterated her constant message that "health is central to development". Since her nomination as Director-General, Brundtland has advocated increased health sector investment in developing countries by demonstrating a strong link between health and economic development. A 2001 report by the WHO Commission on Macroeconomics and Health set specific goals for health investments as a means to promote economic development. Having spent a decade as Norway's prime minister, Brundtland knew that the audience for this key message would ultimately be prime ministers, donors, and finance ministers who can mobilise or reallocate resources for health.

Viewing good health as a means to further economic development is a useful strategy for elevating the status of health-related investment. However, this view also has limitations, particularly in acknowledging the intrinsic value of health and understanding development more broadly. An alternative view of health and economic development sees health as both intrinsically and instrumentally valuable but takes health as an end in itself. This viewpoint sees the opportunity for health and health care as "constituent components of development", 1 obviating the need to justify their importance in terms of their indirect contribution to the growth of gross national product or personal income. It also recognises the interrelatedness among health and other valuable social ends (eg, education) and at the same time emphasises health's importance for individual agency—ie, people's ability to live a life they value.

Good health enables individuals to be active agents of change in the development process, both within and outside the health sector. Increased investment in health requires public action and mobilisation of resources, but it also brings individuals opportunities for social and political participation in health-system reform and implementation. Agency is critical for development overall and for the development and sustainability of effective health systems, and individuals should have the opportunity to participate in political and social choice about public policies that affect them. These key elements are part of an alternative way of thinking about health and development, and several points are relevant to this view.

First, this alternative viewpoint appeals to a particular vision of the good life that is derived from Aristotelian political philosophy ${ }^{2-6}$ and Amartya Sen's capability approach. ${ }^{1,7,8}$ According to Aristotle, society's obligation to maintain and improve health is grounded in the ethical principle of human flourishing, ${ }^{2-6}$ which holds that society is obligated to enable human beings to live flourishing, and thus healthy, lives. Certain aspects of health, in particular, sustain all other aspects of human flourishing because without being alive no 
other human functionings, including agency, are possible. Therefore public policy should focus on individuals' capacity to function, and health policy should aim to maintain and improve this capacity by meeting health needs. This view sees development as expan sion of individual freedom instead of judging development by gross national product or personal income. $1,7,8$

Second, the link between health and economic development is two-directional because health depends on economic development in the same way that economic development depends on health. For example, health and demography can affect income through their impact on labour productivity, savings rates, investments in physical and human capital, and age structure. In the other direction, income can affect health and demography by, for example, improving the ability to obtain food, sanitation, housing, and education and providing incentives to limit family size. ${ }^{9}$ However, inequalities in income and social position can also harm the health of the underdog, as Marmot's work demonstrates. ${ }^{10}$ It is therefore important to integrate strategies for improving health and economic opportunities rather than assuming a one-directional relation going from health to increased affluence.

Third, health improvement and economic development are both linked to individuals' opportunities to exercise their agency and participate in political and social decision making. Political and civil rights, especially the right to open discussion and dissent, are central to informed choice. ${ }^{1}$ Agency is important for public policy because it supports individuals' participation in economic, social, and political actions and enables individuals to make decisions as active agents of change. This view contrasts with the perspective that individuals are passive recipients of health care and decisions about health expenditure or other development programmes. An agency-centred view promotes individuals' ability to understand and "shape their own destiny and help each other". ${ }^{1}$ Development of institutions that aim to improve health and create economic opportunities should therefore be influenced by the "exercise of people's freedoms, through the liberty to participate in social choice and in the making of public decisions that impel the progress of these opportunities". ${ }^{1}$ It is important that any discussion of health and economic development take note of the significance of participation for effective and sustainable reforms. Active agency is critically important for both health and economic development as indeed they are important for each other.

\section{Acknowledgments}

I thank Amartya Sen for helpful comments. Supported in part by grant 1K01DA016358-01 from the National Institutes of Health.

\section{References}

1. Sen, AK. Development as freedom. Knopf; New York: 1999.

2. Aristotle; Welldon, JEC. The Nicomachean ethics. Prometheus Books; Amherst, NY: 1987.

3. Nussbaum, MC. Nature, function, and capability: Aristotle on political distribution.. In: von Gunther Patzig, H., editor. Vandenhoeck and Ruprecht; Aristoteles politik. Gottingen: 1990.

4. Nussbaum, MC. The good as discipline, the good as freedom.. In: Crocker, D., editor. The ethics of consumption and global stewardship. Rowman and Littlefield; Lanham, MA: 1998. p. 312-41. 
5. Nussbaum MC. Human functioning and social justice: in defense of Aristotelian essentialism. Polit Theory. 1992; 20:202-46.

6. Aristotle. The politics. Lord, C., editor. University of Chicago Press; Chicago: 1994.

7. Sen, AK. Inequality reexamined. Harvard University Press; Cambridge: 1992.

8. Sen, AK. Commodities and capabilities. North-Holland; Amsterdam: 1985.

9. Ruger, JP.; Jamison, DT.; Bloom, DE. Health and the economy.. In: Merson, MH.; Black, RE.; Mills, AJ., editors. International public health: disease, programs, systems, and policies. Aspen Publishers; New York: 2001.

10. Marmot, MG.; Bobak, M.; Davey Smith, G. Explorations for social inequalities in health.. In: Amick, BC.; Levine, S.; Tarlov, AR.; Chapman, D., editors. Society and health. Oxford University Press; London: 1995. 